\title{
Nature of Waste and Disposal Practices Among Different Business Holders Around Industrial Area of Rosslyn, Pretoria, South Africa
}

\author{
J.O. Olowoyo $\dagger$, L. Mpagane and S. Nyathi \\ Department of Biology, Sefako Makgatho Health Sciences University, Pretoria, South Africa \\ †Corresponding author: J.O. Olowoyo; woleolowoyo@yahoo.com
}

Nat. Env. \& Poll. Tech. Website: www.neptjournal.com

Received: 09-12-2019

Revised: $06-02-2020$

Accepted: 16-04-2020

Key Words:

Waste disposal

Management

Recycling

\begin{abstract}
Waste disposal and management is a serious concern especially in most of the developing countries. Both big and small business holders may influence the quality of their immediate environment. The present study investigated the nature of waste and attitude of different business units towards waste disposal practices around the industrial area of Rosslyn, Pretoria, South Africa. Mixed method approach was used to carry out the research. 138 questionnaires were administered to owners of small and medium-sized business units and managers of big companies. Questionnaires were used to collect information on the nature of waste and attitude towards waste disposal and management. It was noted that the industrial area in Rosslyn is dominated largely by small and medium-sized business enterprises. The level of education of most of the small-sized business units was below matric level. The most common types of waste generated were papers, plastics and discarded food in some disposable materials. The small business holders did not consider waste separation as an important issue and also the purchase of different waste bins for wastes separations. The small business holders believed that it is the responsibility of the government to provide different waste bins. From the companies that render services to big companies, metals are separated for recycling mainly because they can be sold to other companies. Concern for the environment or human did not have any impact on waste management. The study concluded that though there are waste bins in the study area, these seem inadequate thus leading to improper waste management systems around the industrial area in Rosslyn. Workers and small companies' holders did not see any reason why they should be concerned about proper waste management. Campaigns and education on waste management should be intensified to change attitudes towards proper waste management.
\end{abstract}

\section{INTRODUCTION}

Municipal solid waste disposal has become one of the major challenges both in developed and developing countries all over the world (Wang et al. 2018). This is as a result of urbanization and various developmental projects embarked upon in these countries (Harris-Lovett et al. 2018). Nyakaana (2012) reported that the increase in urban, economic and industrial activities, as well as the resultant population increase, has led to an increase in the quantity of solid waste generated.

In most of the urban city centres, discarded materials such as papers, glasses, bottles and leftover food items in disposable plates littering the roads that tend to accumulate over a prolonged period if not collected have become a permanent feature of most of these cities (Banjo et al. 2009). Hazra \& Goel (2009) and Moghadama et al. (2009) also noted that improper bin collection systems, poor route planning, insufficient bins, poor roads and unwillingness to pay for the removal services have accounted for this phenomenon.

In general, if wastes are not properly collected, transferred and disposed at an approved waste disposal sites, they may decompose, produce methane or pollute both the water and soil within the area (Oyelola et al. 2009). Improper waste disposal may also lead to unsanitary conditions such as leaching of the waste, the spread of odours thereby increasing the risk and spread of diseases and reduction in the aesthetic value of the urban city centre (Edjabou et al. 2012). In some countries, solid wastes are disposed of in open dumpsites creating environmental and community health issues (Singh 2019). Studies have shown that pathogenic bacteria such as Salmonella dysenteriae, Citrobacter freundii, Proteus vulgaris and Escherichia coli have been found in solid waste in major cities when waste is not disposed of (Kirama \& Mayo 2016).

Waste production and management is now considered a serious problem in urban areas, especially from developing countries. Different countries have developed different approaches to address the problems associated with municipal waste management and disposal. In China, fees are attached to the disposal of solid waste which is payable by an individual or the company involved in the generation of waste (Zhang et al. 2012). Also in China, there is a 'polluter pay principle' 
that has been known to influence the generation and disposal of municipal solid waste. In Nigeria, individuals may buy waste bins and contact privately-owned companies which are paid for to assist in the disposal of waste. Waste collected is later disposed of in a dumpsite. Some have also resorted to burning of the wastes. In South Africa, registered houses and companies are supplied with waste bins and are billed at the end of the month for waste management and disposal.

There is a general belief that disposal and management of waste is the sole responsibility of the government (UN-Habitat 2010, Vidanaarachchi et al. 2006). However, if wastes are properly disposed of and managed, it may provide not only job opportunities especially in developing countries but also means of livelihood (Vergara \& Tchobanogious 2012). Medina (2007) had earlier reported that over $2 \%$ of the world's population depends on waste collection, processing and recycling as a means of livelihood.

Over the years, research on waste disposal and management was conducted largely on households within the residential areas with a focus on the nature of waste, family income and the effect of education on waste generation and disposal (Sujauddin et al. 2008, Ekere et al. 2009). Minimum attention has been paid to waste generation and management around industrial areas (Singh 2019, Chu et al. 2019). South Africa like any other developing countries in the world is facing rapid urbanization and more than half of South Africa's population is urbanised. This may increase the generation of waste in South Africa as noted in other developing countries. In South Africa, wastes are usually collected on a specific day of the week depending on the location and area. However, it is not uncommon to see waste littering the streets, especially around the industrial areas. Waste bins are provided and collected around these areas on some specific days just as noted within the residential areas.

The study proposed three hypotheses, Hypothesis 1: Knowledge regarding waste separation and its economic benefit has a positive effect on different business units handling waste. The American Oxford dictionary 2010 edition defines knowledge as "skills acquired by a person through experience or education; the theoretical or practical understanding of a subject". Van Kien (2015) further added that knowledge may also be received through experience leading to contextual information which will assist in providing insight for evaluating and integrating new information through experience. Thus, it is assumed that, the higher the knowledge, the higher the changes in behaviour (Van Kien 2015). Prior knowledge will include appropriate information and importance of waste separation. Dijk et al. (2015) noted that effective education of workers would improve the working conditions of workers and when the educated, the trained worker becomes an integral part of workplace safety programs. We, therefore, assumed that those that are educated or well informed about waste disposal practices will tend to adhere to proper waste management options.

Hypothesis 2: Health and environmental concerns have a positive and significant effect on business units' disposal of waste. Concerns over the overall impact of the work environment may influence attitudes towards safety practices.

Hypothesis 3: Financial implication of waste management and disposal may adversely affect people's behaviour about waste management. The additional cost implication of managing and disposing of waste may influence people's decision on waste management.

The focus of the present study is therefore to investigate both the small business owners and big business owners' attitudes towards waste generation, management and disposal. The study will also attempt to determine factors that may bring about a change in the attitude of business holders in supporting waste disposal and management methods prescribed by the government.

\section{MATERIALS AND METHODS}

\section{Study Site}

The study was conducted around the industrial area of Rosslyn, Pretoria, South Africa. Rosslyn is an industrial area best known for its automotive industries such as BMW and Nissan and also the South African Breweries. There are other smaller industries (formal and informal) operating in this area providing subsidiary services to these big industries. These include roadside food vendors, roadside mechanics and several other retail shops among others. The area usually witnesses an influx of people coming from surrounding areas working and seeking for a job or buying items from the small retail shops around the area. The area was chosen because of the observed presence of different types of waste that are usually noticed when passing through the area (Fig. 1). Business owners were observed in their natural setting on their self-consciousness among others towards proper waste disposal (Kawulich 2005). Yusuf et al. (2019) also noted that population, economic activities and areas are factors that may account for waste generation. The study also checked these factors among the different business units in this area.

In the present research work, business units having more than 25 employees are referred to as big companies (28), 4-9 employees as medium-sized companies (46) and those with 3 or less employee are regarded as small size business units (64). Some of the small-sized business units are using illegal structures to carry out their businesses around the industrial area used for the study. 

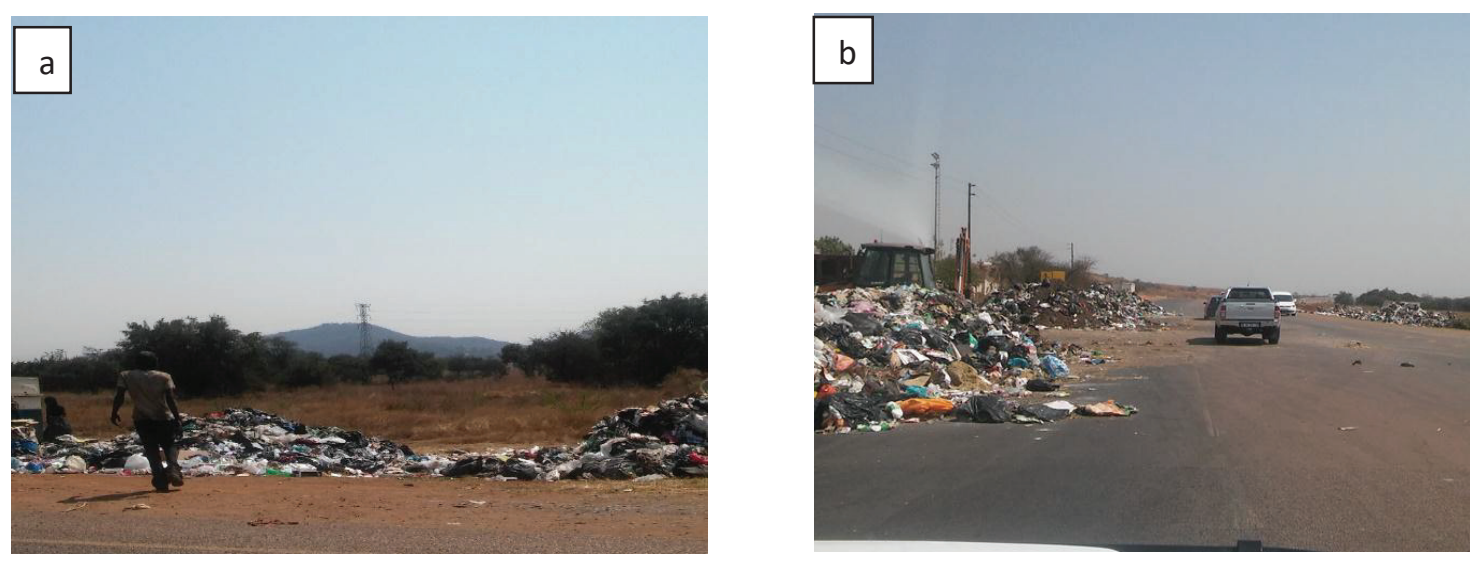

Fig. 1a and b: Waste discarded along the busy road in Rosslyn.

A mixed-method approach was used for the study (Cresswell \& Plano Clark 2011). The method assisted in gaining a deeper and broader understanding of the rationale underlying their attitudes towards waste disposal and management (Creswell 2015). Different business units (Small, medium-sized and big units) were invited to participate in the study around the industrial area of Rosslyn, Pretoria, South Africa. These included food vendors by the roadside, mechanics, retail shops, firms providing services to bigger industries and the big sized companies. This was done to ascertain the perception of these small and "informal" business owners on the importance of proper waste disposal and management. A total of 138 questionnaires were administered to all the business units that agreed to participate in the study.

The questionnaire was designed to understand the perceptions and attitudes of different business units on waste disposal methods and their involvement in managing and disposing of waste correctly. To do this effectively, the questionnaire contained information on the educational level of the business owner, prior information on waste management, awareness and importance of recycling, types of waste that can be reused, nature of waste generated, type of waste generated, attitude towards waste management, the importance of sorting waste, issues around waste and the environment, waste and human health, willingness to pay for additional waste bins and the use of waste bins among others.

\section{RESULTS AND DISCUSSION}

\section{Type of Wastes Generated by the Different Small Business Holders}

The data gathered during the study showed that paper was the most generated waste followed by plastic, metals and construction waste (Fig. 2). Other types of waste generated

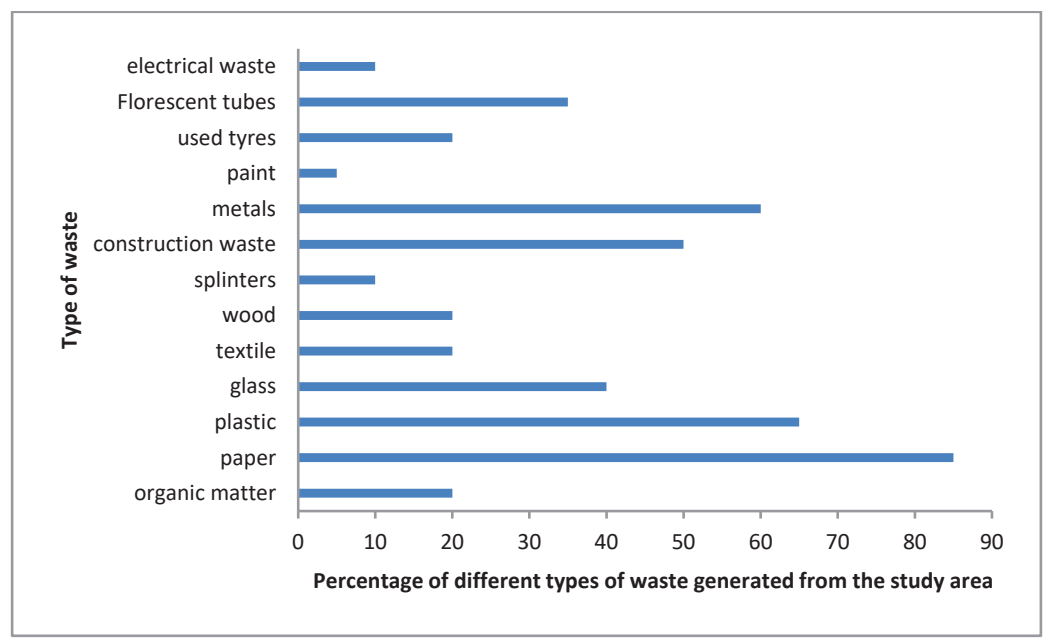

Fig. 2: Different types of waste generated from the study area by all the industries interviewed. 
around this area include glasses, decomposing food items (leftover food items), textile, wood and used tyres. The use of paper in offices and communication may account for the reason why the paper was the most generated waste from all the companies. In addition, most of the companies around the industrial area in Rosslyn that agreed to participate in this study were more of medium to low size business units and they may not be able to afford the use of modern communication gadgets at their workplaces. The use of an electronic method for communication and transaction seems to be low or unacceptable in some of the industries. Our results are in agreement with the findings of Casares et al. (2005) where it was observed in a study from Spain that paper and cardboard, plastic, wood, and metals were the most common types of waste. Koolivand et al. (2017) also noted in a separate study conducted in Iran that metals, organic waste and paper and cardboard constituted about $80.9 \%$ of total waste generated while paper accounted for $49.53 \%$ of the total solid waste generated. The type of wastes generated by different industries as observed in our study depends on the type of industrial processing activities (Salihoglu 2010).

However, there are differences in the type and volume of wastes generated by the different business units interviewed in our study. This is mainly due to the nature of their work. For instance, the small business units generated more waste in terms of organic waste, disposable materials, plastic bags and leftover food items. From the small business units, paper as a form of waste generation was not common when compared to the middle and big sized industries. As noted in our study, the medium-sized industries generated more waste in terms of paper than the big sized industries except for some restaurants. Similar to the food vendors, the waste from the restaurants are plastic bags, disposable plates and leftover food items. All the restaurants interviewed are forced to dispose of their waste properly due to the impression that this may have on their customers. However, other medium-sized industries like those providing services to the big sized industries have papers as the most dominant waste from their businesses. The nature, size and quantity of waste generated by small business holders might have affected their attitudes towards waste separation. In most cases, it is generally assumed that only recyclable waste should be separated for recycling purposes. However, in some other countries, organic wastes are also purchased from household for organic farming thus favouring increased participation in waste separation from all stakeholders. The study of Vicente \& Reis (2008) indicated among other that factors that affect recycling habits include the composition of household material and disposal method.

\section{Waste Management System from the Companies and Small Business Holders}

Most of the companies and both the medium and smallsized business units surveyed $(72.9 \%)$ admitted that they do not separate their waste or follow any waste management system. However, $85 \%$ of the big companies such as metal smelting companies that usually provide services to other big companies such as BMW and Nissan do separate their waste. The remaining $15 \%$ that do not separate their waste mentioned that they do not deal with metals or anything that can be recycled and therefore have no reason to separate their wastes. Those that separate their waste have different types of bin properly labelled for a specific type of waste. Afroz et al. (2008) in a study of factors affecting willingness to recycle which was carried out in Dhaka, Bangladesh showed that willingness to participate in waste recycling was as a result of economic benefits and awareness. This is similar to our findings where it was noted that companies that separate their waste did so for the economic profit and the information they had received about recycling.

From the companies that are willing to separate their waste, it was noticed that they had prior information about waste recycling and since these are registered companies they may be compelled to follow certain environmental law that indicates compliance.

The small and medium business holders that were interviewed had little or no knowledge about recycling and believed that they do not generate waste that can affect the environment and the type of waste they generate cannot be used for other purposes. Kamara (2006) had earlier reported that participation in domestic waste disposal and recycling in the Tshwane metropolitan area was low due to the level of awareness as regards sorting, recycling and disposal of domestic waste. Mohai (1985) noted that decisions and attitudes towards the environmental protection effort depend on degrees of personal efficacy and resource availability. The report of the findings of Kumar \& Nandini (2013) from a study conducted in Karnataka, India also noted that most individuals are not willing to separate their waste because they have enough spaces either on the road or open spaces where it can be deposited and it is largely the duty of the municipality or the government.

Furthermore, on waste separation, all the medium and small business units are not willing to buy different bins for waste separations.

However, since the questionnaire shed more light on the importance of waste separation the respondents from medium-sized companies are willing to do it, if the government can provide bins for this purpose.

Separation of wastes was also considered as labour intensive especially from food vendors and those with small businesses. Most of those interviewed argued that it will generally be difficult for them to separate waste while trying to attend to their customers or when they are tired 
in the evening and about to go home. One of the respondents said, "It is easier to just put it all in a waste plastic and throw it in the big bin outside". Another respondent replied, "Government should employ people that will help us to separate the waste and by so doing will provide job opportunities for the other".

This view is similar to those reported by $\mathrm{Li}$ (2003) in a study carried out in China where it was reported that households with more family member have more time to do recycling because they can distribute the household works between the household members while larger family size, households may face more waste and are therefore more willing to recycle.

On the other hand, most of the smaller companies reported that once the waste bin provided by the government is full, wastes are usually discarded in a black or green plastic bag and deposited next to the already full waste bins (Fig. 3). The food vendors and others selling perishable goods reported that they do not have a waste bin rather a waste plastic bag which is usually deposited next to government waste bin when it is full. They reported that due to stealing of the government waste bin, most of the business owners around the area have resulted to the use of black or green plastic waste bags and are usually placed in a conspicuous place for removal by the responsible authorities (Figs. 3a and 3b).

Except for some big companies that are involved in the waste separation, none of the small business holders is willing to buy a big waste bin, hence the deposition and littering of the business area around this area (Figs. 4a and 4b). It was also observed and reported that, if the waste that littered the environment are not collected on time, some of the small business units have resorted into illegal burning of these wastes (Figs. 5a and 5b). The unavailability of waste bin provided by the government may be a serious cause for concern if wastes are to be properly deposited in this area. Dauda et al. (2015) noted in a study from Berekun Municipality, Ghana that inadequate bins and long distance are major factors for solid waste management in the area. Scharfe (2010) mentioned that solid waste disposal and management have been neglected and given low priority from most African countries.
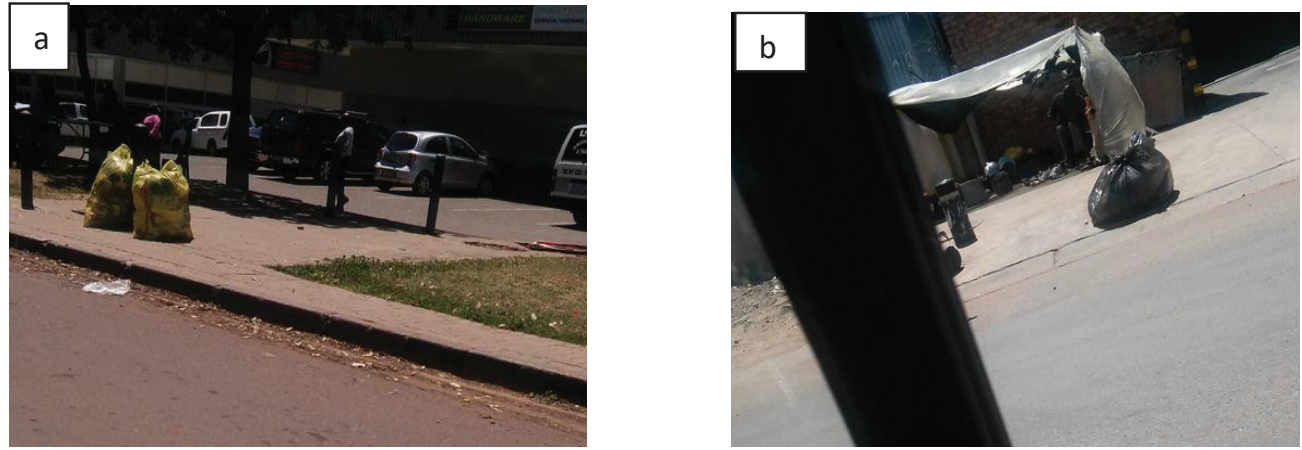

Fig. 3a and b: Waste wrapped properly on the streets of Rosslyn when the waste bin was full and not collected.
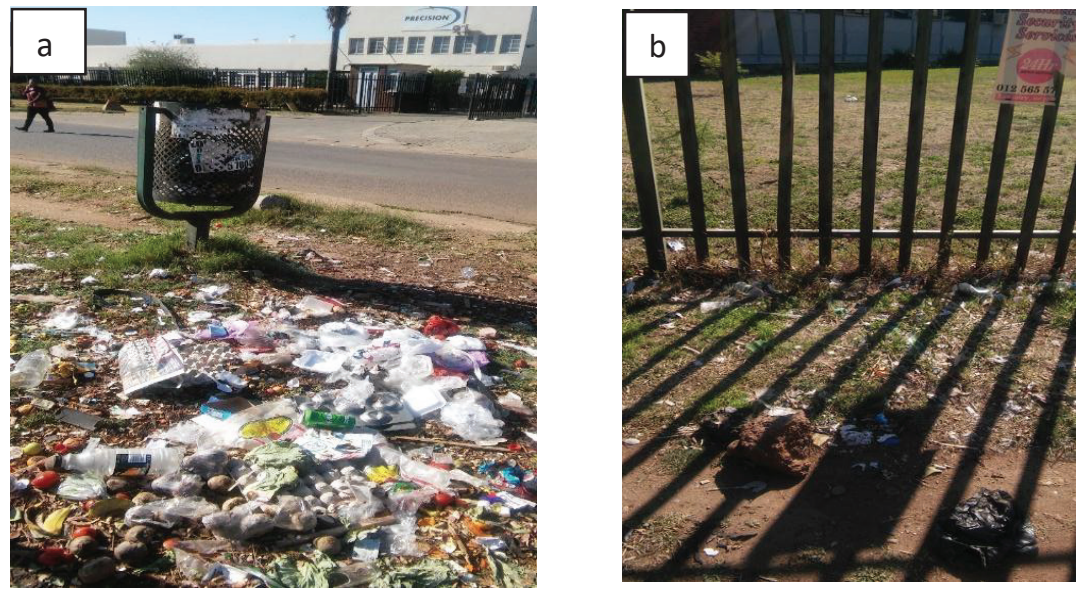

Fig. 4a and b: Waste deposited around the waste bin provided by the government and (b) littered waste around the industrial area of Rosslyn 

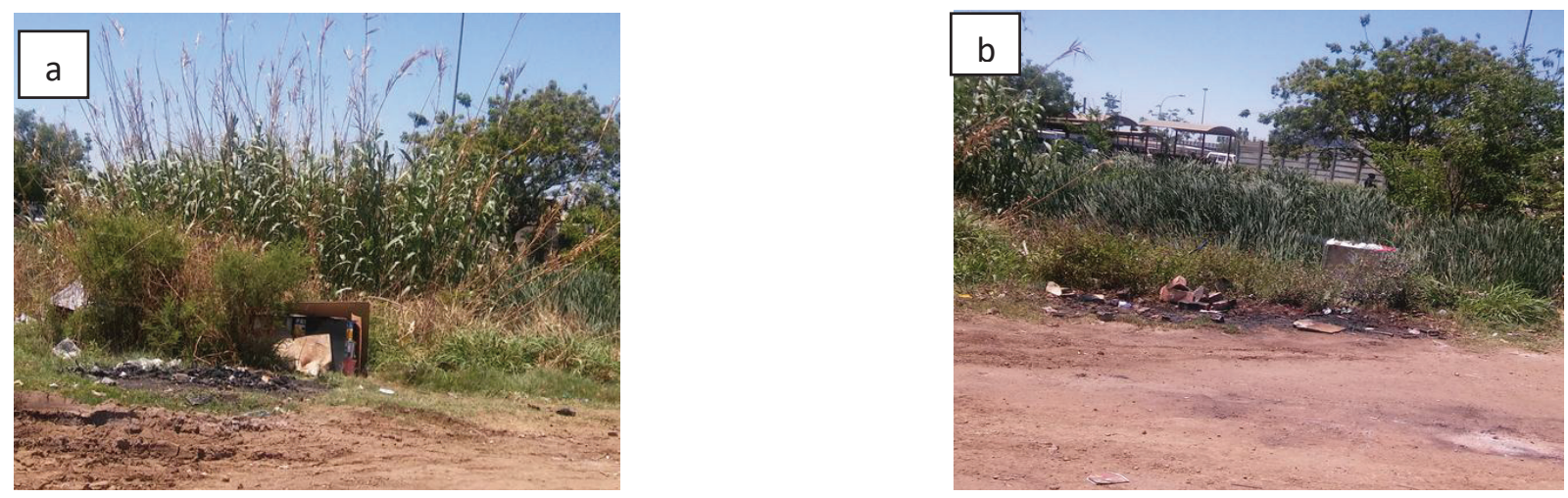

Fig. 5a and b: Illegal burning of waste around the industrial area of Rosslyn.

\section{Willingness to Pay for Waste Removal from Individual Business Centres}

Those operating and providing services to big companies mentioned that they are levied monthly for waste removal and management. They are not willing to pay an extra amount for the service they've paid for. None of the small business owners interviewed is willing to pay more on waste removal. Some of those interviewed reiterated that "We are currently struggling to make a living, we cannot pay anything, and government must remove the waste".

The major reason for not willing to pay according to the small business owners interviewed was that they have low income and have big families to cater for. A similar observation was noticed in the study conducted by Dauda et al. (2015) in Ijebu Ode, Nigeria where respondent indicated that it is the responsibility of the government to pay for the collection and management of waste.

\section{CONCLUSIONS}

The present study investigated the attitudes of different business units on the disposal and management of waste around an industrial area of Rosslyn in Pretoria, South Africa. Three hypotheses were formulated to understand the attitude towards waste disposal and management. It was noted from the study that knowledge about waste disposal did not have any influence on small business units because most of the small business units believed that proper waste disposal was not their duty. Concerns for health and environment was of no issue from all the groups studied but some considered it important to dispose of waste properly just because of the health implication. None of the business units will accept an increase or introduction of fees for proper waste disposal. Improper waste management is a major problem in the area used for the present study. Most of the small business units termed as either small or medium in the present study constructed illegal structures and are not registered hence the difficulty on the part of the government to either charge them for waste management or provide waste bins for them individually. Papers were seen littering the entire area with several illegal burning of waste. It was discovered from the study that the type and composition of waste depend largely on the type, size and their processes. Papers and leftover food were common forms of waste generated in the area. Knowledge and awareness on the reuse of waste especially the organic waste is still very low among those interviewed. The area is largely dominated by both the small and medium-sized companies that are without waste bins hence the littering of the areas with different types of waste. Small company's holders did not see any reason why they should be concerned about proper waste management. The government should intensify effort on producing enough waste bins that are properly locked or chained to an object to prevent theft. Campaigns and education on proper waste management, disposal and recycling (organic and inorganic) should be intensified to change attitudes towards proper waste management.

\section{REFERENCES}

Afroz, R., Hanaki, K and Kurisu, K.H. 2008. Factors affecting waste generation and willingness to recycle: a study in a waste Management Program in Dhaka city, Bangladesh. FEB Working Paper Series No. 0803, 2-17.

Banjo, A.D., Adebambo, A.A.R. and Dairo, O. S. 2009. Inhabitants' on domestic waste disposal in Ijebu Ode, Southwest Nigeria. African Journal of Basic \& Applied Sciences, 1(3-4): 62-66.

Casares, M.L., Ulierte, N., Mataran,A., Ramos, A. and Zamorano, M. 2005. Solid industrial waste and their management in Asegra (Granada Spain). Waste Management, 25(1): 1075-1082.

Chu, Z., Wang, W., Zhou, A. and Huang, W. 2019. Charging for municipal solid waste disposal in Beijing. Waste Management, 94: 85-94.

Cresswell, J.W. and Plano Clark, V.L. 2011. Designing and Conducting Mixed Methods Research. $2^{\text {nd }}$ ed., Los Angeles, CA: Sage.

Creswell, J.W. 2015. Educational research: Planning, Conducting, and Evaluating Quantitative and Qualitative Research. 5th ed., Boston, MA: Pearson. 
Dauda, S., Mariwah, S. and Agyapong, R. 2015. Residents' perceptions and attitudes towards urban solid waste management in the Berekum Municipality, Ghana. Oguaa Journal of Social Sciences, 7(2): 25-37.

Dijk, F.J., Bubas, M., and Smits, P.B. 2015. Evaluation studies on education in occupational safety and health: Insipiration for development economies. Annals of Global Health, 81(4): 548-560.

Edjabou, M.E., Moller, J. and Christensen, T.H. 2012. Solid waste characterization in Keteo, a rural town in Togo, West Africa. Waste Management and Research, 30(7): 745-749.

Ekere, W., Mugisha, J. and Drake, L. 2009. Factors influencing waste separation and utilization among households in the Lake Victoria Crescent, Uganda. Journal of Waste Management, 29: 3047-3051.

Harris-Lovett, S., Lienert, J. and Sedlak, D.L. 2018. Towards a new paradigm of urban water infrastructure: identifying goals and strategies to support multi-benefit municipal wastewater treatment. Water, 10(9): 1127.

Hazra, T. and Goel, S. 2009. Solid waste management in Kolkata, India: Practices and challenges. Waste Management, 29(1): 470-478.

Kamara, A.J. 2006. Household Participation in Domestic Waste Disposal and Recycling in the Tshwane Metropolitan Area: An Environmental Education Perspective. Dissertation. University of Southern Africa, South Africa.

Kawulich, B.B. 2005. Participant observation as a data collection method [81 paragraphs]. Forum Qualitative Sozialforschung/Forum: Qualitative Social Research, 6(2), Art. 43. Available:http://www.qualitativeresearch.net/index.php/fqs/article/view/466/996 [Accessed: 21 September 2019].

Kirama, A. and Mayo, A.W. 2016. Challenges and prospects of private sector participation in solid waste management in Dar es Salaam City, Tanzania. Habitat International, 53: 195-205.

Koolivand, A., Mazandaranizadeh, H., Binavapoor, M., Mohammadtaheri, A. and Saeedi, R. 2017. Hazardous and industrial waste composition and associated management activities in Caspian industrial park, Iran. Environmental Nanotechnology, Monitoring \& Management, 7: 9-14.

Kumar, M. and Nandini, N. 2013. Community attitude, perception and willingness towards solid waste management in Bangalore city, Karnataka, India. International Journal of Environmental Sciences, 4(1): 87-95.

Li, S. 2003. Recycling behaviour under China's social and economic transition. Environment and Behaviour, 35(6): 784-801.

Medina, M. 2007. The world's scavengers: Salvaging for sustainable consumption and production. AltaMira Press, Lanham.

Moghadama, M.R.A., Mokhtaranib, N and Mokhtaranic, B. 2009. Municipal solid waste management in Rasht City, Iran. Waste Mnagement, 29: 485-489.
Mohai, P. 1985. Public Concern and Elite Involvement in EnvironmentalConservation Social Science Quarterly. 4(66): 820.

Oyelola, O.T., Babatunde, A. I. and Odunlade, A. K. 2009. Health implications of solid waste disposal: Case study of Olusosun dumpsite, Lagos, Nigeria. International Journal of Pure and Applied Sciences. 3(2): $1-8$.

Salihoglu, G. 2010. Industrial hazardous waste management in Turkey: Current state of the field and primary challenges. Journal of Hazard Matter: 177(1-3): 42-56.

Scharfe, D. 2010. Integrated Waste Management Plan, Centre \& South Waste Services Board/ Waste Diversion Ontario and Stewardship Ontario.

Singh, A. 2019. Managing the uncertainty problems of municipal solid waste disposal. Journal of Environmental Management 240: 259-265.

Sujauddin, M., Huda, M.S. and Rafiqul Hoque, A.T.M. 2008. Household solid waste characteristics and management in Chittagong, Bangladesh. Journal of Waste Management, 28: 1688-1695.

UN-Habitat. 2010. Solid Waste Management In The Worlds' Cities. Nairobi: UN-Habitat.

Van Kien 2015 . Nearly $\% 50$ of the public official candidates have lobbied. Tien Phong, Issue April 15 2015. Accessed 12 May 2015. http:// www.tienphong.vn/xa-hoi/chi-so-papi-2014-gan-50-phai-lot-tay-devao-cong-chuc-847508.tpo [Google Scholar]

Vergara, S.E. and Tchobanoglous, G. 2012. Municipal solid waste and the environment: A global perspective. Annual Review of Environment and Resources 37(1): 277-309.

Vicente, P. and Reis, E. 2008. Factors influencing households' participation in recycling. Waste Management \& Research, 26: 140-146.

Vidanaarachchi, C.K., Yuen, S.T.S. and Pilapitiya, S. 2006. Municipal solid waste management in the Southern Province of Sri Lanka: problems, issues and challenges. Journal of Waste Management, 26: 920-930.

Wang, H., Fan, X., Wang, Y.N., Li, W., Sun, Y., Zhan, M. and Wu, G. 2018. Comparative leaching of six toxic metals from raw and chemically stabilized MSWI fly ash using citric acid. Journal of Environmental Management, 208: 15-23.

Yusuf, R.O., Adeniran, J.A., Mustapha, S.I. and Sonibare, J.A. 2019. Energy recovery from municipal solid waste in Nigeria and its economic and environmental implications. Environmental Quality Management, 28 (3): $33-43$

Zhang, H.W. 2012. Research on current situation and counter measures of disposal of rural domestic garbage in Shandong province. China High-Tech Enterprises 24: 105-107. 